\title{
Microbiome of the larvae of Spodoptera frugiperda (JE Smith) (Lepidoptera: Noctuidae) from maize plants
}

\section{Ugwu, Juliana Amaka}

2020-11

Ugwu , J A , Liu , M , Sun , H \& Asiegbu , F O 2020 , ' Microbiome of the larvae of Spodoptera frugiperda (JE Smith) (Lepidoptera: Noctuidae) from maize plants ' , Journal of Applied Entomology , vol. 144 , no. 9 , pp. 764-776 . https://doi.org/10.1111/jen.12821

http://hdl.handle.net/10138/335862

https://doi.org/10.1111/jen.12821

acceptedVersion

Downloaded from Helda, University of Helsinki institutional repository.

This is an electronic reprint of the original article.

This reprint may differ from the original in pagination and typographic detail.

Please cite the original version. 


\title{
Microbiome of the larvae of Spodoptera frugiperda (J.E. Smith) (Lepidoptera: Noctuidae) from maize plants
}

\author{
Juliana Amaka Ugwu ${ }^{1,2}$ (iD \\ Mengxia Liu' ${ }^{2}$ (D) | Hui Sun ${ }^{2,3}$ \\ Fred O. Asiegbu ${ }^{2}$
}

\begin{abstract}
${ }^{1}$ Forestry Research Institute of Nigeria, Ibadan, Nigeria

${ }^{2}$ Department of Forest sciences, University of Helsinki, Helsinki, Finland

${ }^{3}$ Nanjing Forestry University, Nanjing, China

\section{Correspondence}

Juliana Amaka Ugwu, Department of Forest sciences, University of Helsinki, P.O Box 27, FIN-00014 Helsinki, Finland.

Emails: dr.amaka2013@gmail.com; juliana. ugwu@helsinki.fi
\end{abstract}

Funding information

Schlumberger Foundation

\begin{abstract}
Fall armyworm (FAW), Spodoptera frugiperda, is an invasive insect pest with a diverse host range threatening food security in the African continent by causing severe economic damage to staple maize crop. FAW like all other insects are associated with various microbiota that influence their several characteristics and activities. The microbiota of insects plays important roles in their growth, development and environmental adaptation to their host plants or animals and not much is known about microbiota of FAW in Nigeria. In this study, the microbial community of FAW larvae from maize plants in Nigeria was investigated using Illumina PE250 NovaSeq of 16S rRNA V3-V4 gene region. A total of 1,160,133 sequence reads that ranged from 83,794 to 145,475 were obtained. They span through 2 kingdoms: bacteria (99.59\%) and archaea (0.37\%), 37 phyla, 59 classes, 78 orders, 145 families and 285 genera. The dominant taxonomic group of bacteria across the larval samples were Proteobacteria (58.32\%), Firmicutes (35.87\%) and Bacteroidetes (4.02\%). There were no significant differences in bacteria species diversity and richness among the individual fall armyworm larva and samples from different geographical regions. The relative abundance of Bacteria phyla and classes also showed no significant differences among the larval samples. Significant differences were documented in bacteria orders Acidobacteriales and Aeromonadales, family Acidobacteriaceae_ (Subgroup_1) and genera Novosphingobium and Pedobacter. The results indicate that the gut of FAW larvae harbours a diverse set of bacteria and archaea biota. Understanding their ecological and functional relevance would provide novel insight on potential approaches for their exploitation in the integrated management of FAW in the tropics.
\end{abstract}

KEYWORDS

16S rRNA sequencing, archaea, fall armyworm, gut bacteria, invasive pest, maize host

\section{1 | INTRODUCTION}

Insects are the most successful group of animals in the universe in diversity and survival in almost all the ecological niches. The fall armyworm (FAW), Spodoptera frugiperda (J.E. Smith) (Lepidoptera: Noctuidae), is an invasive insect and a highly polyphagous pest of the American origin (Cock, Beseh, Buddie, Cafa, \& Crozier, 2017; Pogue, 2002; Todd \& Poole, 1980). They attack several agricultural crops of more than 180 plant species in 42 families (Ram, 2019), including maize (Casmuz et al., 2010; Silva et al., 2017). Maize and other economically important staple food crops in Africa are severely damaged by S. frugiperda larvae (Day et al., 2017) causing great economic losses and endangering food security in the region (CABI, 2018). FAW destroys young maize plants by attacking their growing points and burrows into cobs in older plants, thus affecting the yield quantity and quality severely (FAO, 2018). The larvae 
generally stay inside the plant tissue and move into the soil to pupate and later emerge as adults. In maize, this pest has historically been controlled with synthetic insecticides, but their effectiveness is restricted because the larvae hide inside the maize whorl (Carvalho, Omoto, Field, Williamson, \& Bass, 2013) and have developed resistance to several insecticides (Carvalho et al., 2013; Nascimento, Farias, Bernardi, Horikoshi, \& Omoto, 2016). FAW has also developed field-evolved resistance to Bacillus thuringiensis (Bt) maize (Chandrasena et al., 2018; Farias et al., 2014; Huang et al., 2014; Omoto et al., 2016; Storer et al., 2010). Bacillus thuringiensis (Bt) maize is a transgenic crop that produces insecticidal proteins, which are currently the most successful biotechnological pest management application (Sanchis, 2011). FAW like other insects is known to live in close association with many microorganisms. They harbour various microbial communities that influence their interaction with other trophic levels and their environment (Acevedo et al., 2017). The insect host is affected by the actions and interactions of all the microbiota components such as bacteria, archaea, fungi, protozoa and viruses (Gurung, Wertheim, \& Falcao Salles, 2019). Microorganisms are essential for plant-feeding insects whose diet is generally either low in nutrients, high in chemical defences or both. Insect-associated microorganisms provide several functions such as provision of nutrients, regulation of insect-immune responses, synthesis of pheromone and protection against parasites and predators (Douglas, 2015; Engel \& Moran, 2013; Kikuchi et al., 2012). In insects, symbiotic bacteria play important roles in host physiology such as providing essential amino acids, prompting resistance against insecticides (Kikuchi et al., 2012), aid in digestion (Visotto, Oliveira, Ribon, Mares-Guia, \& Guedes, 2009) and detoxify plant secondary metabolites such as terpenes and phenolics (Hammer \& Bowers, 2015). Bacteria found in the regurgitated food can also influence plant responses to herbivore feeding by suppressing plant defences induction and increasing herbivore growth (Chung et al., 2013; Wang et al., 2016).

The common associations between insect guts and bacteria are facultative in nature and seem to perform context-reliant functions (Manson, Jones, \& Felton, 2018). Caterpillars (larvae) of Lepidoptera have been suggested to naturally lack resident gut symbionts (Hammer, Janzen, Hallwachs, Jaffe, \& Fierer, 2017). Associated bacteria have been studied in $<0.1 \%$ of larvae of the recognized lepidopteran species using meta-taxonomics (Marchesi \& Ravel, 2015), which revealed that current knowledge about the lepidopteran microbiome, and their roles is still very inadequate (Voirol, Frago, Kaltenpoth, Hilker, \& Fatouros, 2018). Insect microbiomes could be determinant of the outcome of pest-natural enemies-host plant interactions (Ferrari, Vavre, \& Lyon, 2011). Approaches that involve altering insect microbiomes are presently being evaluated for control and management of pests and vectors of plant diseases (Arora \& Douglas, 2017; Beck \& Vannette, 2017; Crotti et al., 2012; PerillaHenao \& Casteel, 2016). The resident microbiota have great potential to be used as improved control methods (Douglas, 2015). It is therefore of importance to gain insight into the composition and functional role of FAW gut microbiota. A study by Acevedo et al. (2017) on FAW gut bacteria using culture-dependent methods to isolate gut bacteria from oral secretions of field-collected larvae revealed that the bacterial isolates regulated herbivore-induced defences. A recent study by Rozadilla, Cabrera, Virla, Greco, and McCarthy (2020) using meta-transcriptomic analysis revealed the presence of novel genes and other components in the gut microbiota of FAW larvae that were being expressed by the community. In this study, we used next-generation paired-end amplicon sequencing of $16 \mathrm{~S}$ rRNA gene to characterize the microbiota of FAW larvae collected from maize plants in Nigeria. The diversity and potential functional roles of the identified microbiota were further discussed.

\section{2 | MATERIALS AND METHODS}

\section{1 | Sample collection}

The larvae of FAW S. frugiperda were randomly collected from maize plants at vegetative stage in the field from eleven different locations within three agroecological zones in Nigeria: namely, southeast, southwest and north (Table 1). Nigeria has a tropical climate with variable rainy and dry seasons depending on location. The southeastern Nigeria is of the wet tropical type climate with mean annual temperature in the range of between 27 and $34^{\circ} \mathrm{C}$.South-western temperature ranged between 21 and $34^{\circ} \mathrm{C}$, while the northern Nigeria temperature can rise up to $44^{\circ} \mathrm{C}$ during the dry season.

Larvae were collected from the same maize variety known as OBA SUPPER 11, which matures in 90 days. Sampling was based on the availability of larvae in the field at the time of collection. Larval samples were collected from maize whorls during the rainy season (April to August 2019) and were preserved in $75 \%$ ethanol until use. The fifth-instar larvae used for this study were sorted from the pool of field samples in the laboratory using morphological characteristics of the $S$. frugiperda instars from the previous biology study of $S$. frugiperda.

\section{2 | DNA extraction}

Genomic DNA was extracted from 32 individual fifth-instar larvae sorted out from the samples using CTAB extraction buffer by grinding the insect tissue in liquid nitrogen with mortar and pestle. The ground sample was transferred to $2-\mathrm{ml}$ tube followed by the addition of extraction buffer (pre-heated at $65^{\circ} \mathrm{C}$ ) and DTT $(1 \mathrm{~mol} / \mathrm{L})$. The mixture was vortexed and incubated for $20 \mathrm{~min}$ at $60^{\circ} \mathrm{C}$ (shaker, $900 \mathrm{rpm}$ ). One volume of chloroform: isoamyl alcohol (24:1) was added, mixed and centrifuged at $10,000 \mathrm{~g}$ for $10 \mathrm{~min}$. The upper phase was transferred to a new tube, and RNase A was added at $100 \mu \mathrm{g} / \mathrm{ml}$ final concentration and then incubated at $37^{\circ} \mathrm{C}$ for $1-2 \mathrm{hr}$. One volume of chloroform/ isoamyl alcohol (24:1) was added, mixed and centrifuged for $10 \mathrm{~min}$ at $10,000 \mathrm{~g}$. The supernatant was transferred into a new $1.5-\mathrm{ml}$ tube, and $1 / 10$ volume of $\mathrm{NaAc}(3 \mathrm{M})$ and 1 volume of isopropanol (at room temp) were added and incubated for $10 \mathrm{~min}$ at room temperature and centrifuged for $30 \mathrm{~min}$ at $10,000 \mathrm{~g}$ at $4^{\circ} \mathrm{C}$. The supernatant was discarded, and pellet was washed with $70 \%$ ethanol by centrifuging for 


\begin{tabular}{|c|c|c|c|}
\hline Sample 1D & $\begin{array}{l}\text { Agroecological } \\
\text { zones }\end{array}$ & Locations & Coordinate \\
\hline B1-A & $A$ & Abia (Umuahia) & $\begin{array}{l}\text { Latitude } 5.54^{\circ} \mathrm{N} \text {; longitude } \\
7.48^{\circ} \mathrm{E}\end{array}$ \\
\hline C1-B & B & Osun (isoka mopa) & $\begin{array}{l}\text { Latitude, } 7.20^{\circ} \mathrm{N} ; \\
\text { longitude, } 4.11^{\circ} \mathrm{E}\end{array}$ \\
\hline $\mathrm{C} 2-\mathrm{C}$ & B & Lagos (Akoka Yaba) & $\begin{array}{l}\text { Latitude, } 6.27^{\circ} \mathrm{N} \\
\text { longitude, } 3.23^{\circ} \mathrm{E}\end{array}$ \\
\hline D1-D & B & Osun (Ile-Ife) & $\begin{array}{l}\text { Latitude, } 7.49^{\circ} \mathrm{N} \\
\text { longitude, } 4.55^{\circ} \mathrm{E}\end{array}$ \\
\hline B2-E & C & Kogi (Anyigba) & $\begin{array}{l}\text { Latitude, } 7.29^{\circ} \mathrm{N} \\
\text { longitude, } 7.11^{\circ} \mathrm{E}\end{array}$ \\
\hline B3-F & C & Kano (Karaye) & $\begin{array}{r}\text { Latitude, } 11.78^{\circ} \mathrm{N} ; \\
\text { longitude, } 8.01^{\circ} \mathrm{E}\end{array}$ \\
\hline D6-G & C & Niger (New Bussa) & $\begin{array}{l}\text { Latitude } 9.53^{\circ} \mathrm{N} \text {; longitude } \\
4.31^{\circ} \mathrm{E}\end{array}$ \\
\hline $\mathrm{D} 2-\mathrm{H}$ & $A$ & Cross River (Calabar) & $\begin{array}{l}\text { Latitude, } 4.95 \mathrm{~N} \text {; longitude, } \\
\text { 8.34 E }\end{array}$ \\
\hline D3-I & $A$ & Enugu (Enugu-Ezike) & $\begin{array}{l}\text { Latitude, } 6.94^{\circ} \mathrm{N} \\
\text { longitude, } 7.45^{\circ} \mathrm{E}\end{array}$ \\
\hline D5-J & B & $\begin{array}{l}\text { Oyo } \\
\text { (Akinyele-Ibadan) }\end{array}$ & $\begin{array}{l}\text { Latitude, } 7.29^{\circ} \mathrm{N} ; \\
\text { longitude, } 3.54^{\circ} \mathrm{E}\end{array}$ \\
\hline D4-K & B & Oyo (Idishin-Ibadan) & $\begin{array}{l}\text { Latitude } 7.41^{\circ} \mathrm{N} \text {, longitude, } \\
3.85^{\circ} \mathrm{E}\end{array}$ \\
\hline
\end{tabular}

TABLE 1 The sample collection locations and their coordinates

${ }^{\mathrm{a}} \mathrm{A}=$ southeast; $\mathrm{B}=$ southwest $\mathrm{C}=$ north.

$5 \mathrm{~min}$ at $10,000 \mathrm{~g}$ at $4^{\circ} \mathrm{C}$. The supernatant was discarded, and the pellet was dried in a sterile hood and resuspended in TE buffer. Samples were quantified with NanoDrop $2000 \mathrm{C}$ Spectrophotometer (Thermo Scientific) according to manufacturer's protocol.

\section{3 | Illumina NovaSeq system}

Samples were submitted to Novogene Bioinformatics Technology (UK) for paired-end sequencing of the 16S rRNA V3-V4 region on the Illumina NovaSeq system, where the primers CCTAYGGGRBGCASCAG and GGACTACNNGGGTATCTAAT were used for the generation of the V3-V4 region amplicon (Klindworth et al., 2013).

Amplicon was performed on a paired-end Illumina platform to generate 250-bp paired-end raw reads (raw PE) and then assembled and pre-treated to obtain clean tag.

The original data obtained from the high-throughput sequencing platforms were transformed to sequenced reads by base calling. Raw data were recorded in a FASTQ file, which contains sequenced reads and corresponding sequencing quality information (Cock, Fields, Goto, Heuer, \& Rice, 2010).

\subsection{Sequencing data processing}

Paired-end reads were assigned to samples based on their unique barcode and truncated by cutting off the barcode and primer sequence and were merged using FLASH (V1.2.7, http://ccb.jhu.edu/ software/FLASH/), and the splicing sequences were called raw tags (Magoč \& Salzberg, 2011).

Quality filtering on the raw tags was performed under specific filtering conditions to obtain the high-quality clean tags (Bokulich et al., 2013) according to the Qiime (V1.7.0) http://qiime.org/scripts/ split_libraries_fastq.html) (Caporaso et al., 2010)) quality-controlled process. The tags were compared with the reference database (Gold database, http//drive5.com/uchime/uchime_download.html) using UCHIME algorithm (UCHIME Algorith http://www.drive5.com/ usearch/manual/uchime_algo.html) (Edgar, Haas, Clemente, Quince, $\&$ Knight, 2011) to detect chimera sequences, and then, the chimera sequences were removed according to Haas et al. (2011). The effective tags were finally obtained. All sequence reads were archived in the Sequence Read Archive under the BioProject: PRJNA631705.

\subsection{OTU cluster and taxonomic annotation}

Sequence analysis was performed by UPARSE software (UPARSE v7.0.1001 http://drive5.com/uparse/) (Edgar, 2013) using all the effective tags. Sequences with $\geq 97 \%$ similarity were assigned to OTUs. Representative sequence for each OTU was screened for further annotation. For each representative sequence, Mothur software was performed against the SSUrRNA database of SILVA Database (http://www.arb-silva.de/) (Wang, Garrity, Tiedje, \& Cole, 2007) for species annotation at each taxonomic rank (threshold: $0.8 \sim 1$ ) (Quast et al., 2012) (kingdom, phylum, class, order, family, genus, 
species). OTU abundance information was normalized using a standard of sequence number corresponding to the sample with the least sequences (D4-K), and after the normalization, it was not used further for detailed analysis because of low sequence depth. Subsequent analysis of alpha diversity and beta diversity was all performed based on this output-normalized data. The sequences from three sample replicates in each sample were pooled together; the sequences were analysed to estimate the overall bacterial diversity and richness in each sample. Species richness was estimated using a rarefaction curve and the richness estimators Chao (Chao, 1984) and ACE (Chao \& Lee, 1992), whereas the Shannon-Weaver index provides more information about community composition and evenness by considering relative abundances (Kim et al., 2017). Rarefaction curve was created by randomly selecting certain amount of sequence data from the samples, and then counting the number of the species, they represent (i.e. the number of OTUs).

\subsection{Statistical analyses}

Multiple sample analysis of molecular variance (AMOVA) $R$ was used to test the significant differences in microbial diversity within the populations between individual larval samples from different locations. Permutational analysis of variance (PERMANOVA) pairwise comparison was conducted to compare sample groups from different geographical regions, while principal component analysis (PCA) was used to compare bacteria community structures across all samples based on the relative abundance of bacteria phyla or genus using SPSS version 25 software. A $p$ value of $<.05$ was considered statistically significant.

Non-parametric independent-samples Kruskal-Wallis test was used to determine the minimum significant difference $(p<.05)$ in relative abundance, species richness (Chao 1 ) and diversity index (Shannon) of bacteria between samples using IBM SPSS Statistics 25.

\section{RESULTS}

\section{1 | Illumina sequencing data}

Paired-end sequencing of the V3-V4 region of the 16S rRNA gene yielded total raw sequence reads of 1,160,133 with average sequence lengths of 397-426 bp from the Illumina NovaSeq sequencer. The sequences were assigned to the domains archaea and bacteria. All the reads had phred score greater than 30 (>Q30; error probability $\geq 0.001$ ), and the average GC content in the range $51 \%-56 \%$ was observed in each sequence reads (Table S1). Application of quality filtering on the raw tags under specific filtering conditions according to the Qiime quality-controlled process resulted in 1,009,546 reads. Effective tags after removing the chimera sequence were 959,298 reads. The average base length of effective tags was 417-428 bp. The pre-processed reads from all samples were pooled and clustered into 1,420 OTUs based on their sequence similarity (similarity cut-off $=0.97$ ), and 836 OTUs were identified from 959,298 after filtering to eliminate OTUs that could arise from sequencing errors and contamination. Successive analysis of alpha diversity and beta diversity was performed based on these normalized output data. A rarefaction curve was constructed for each sample to assess the sequencing depth and the species richness. The dilution curves of the final intergroup samples are presented in Figure 1.

\subsection{Bacteria community richness and diversity of S. frugiperda larvae}

The larval samples from the different locations showed high microbial diversity and OTU species richness with small variation. The highest diversity was found in sample collected from Abia State (B1-A) with Shannon index of 3.9, and the highest species richness (Chao 1) was found in sample collected from Niger State (D6-G), while sample from isoka mopa-Osun State (C1-B) showed the lowest diversity and species richness (Table S2). There were no statistically significant differences in the microbial diversity and species richness of $S$. frugiperda from different agroecological regions ( $p$ value: .423) (Kruskal-Wallis test). However, species richness appeared to be higher in S. frugiperda from south-east region (A) and lowest in samples from south-west region (B) (Table 2).

\section{3 | Bacteria community distribution and composition in $S$. frugiperda larvae identified by Illumina sequencing}

The composition of bacteria present in the S. frugiperda larvae was grouped into each taxonomic category from phyla level to genus

TAB LE 2 Sequencing analysis of 16S rRNA gene amplicons of Spodoptera frugiperda from different agroecological regions with diversity indices

\begin{tabular}{lcccccc}
$\begin{array}{l}\text { Samples from different } \\
\text { agroecological regions }\end{array}$ & No. of sequences & OTU coverage (\%) & Observed OTU & Chao1 & ACE & Shannon \\
\hline A & $1,108,416,667$ & 74.9 & $3,863,333$ & $4,441,477$ & $4,584,143$ \\
\hline B & $12,129,375$ & 83.9 & 3,275 & $3,139,185$ & $3,230,148$ \\
C & 114,138 & 85.8 & 330 & 341,529 & $3,467,923$ & 2.2 \\
\hline
\end{tabular}

${ }^{\mathrm{a}} \mathrm{A}=$ south-east; $\mathrm{B}=$ south-west; $\mathrm{C}=$ north. 


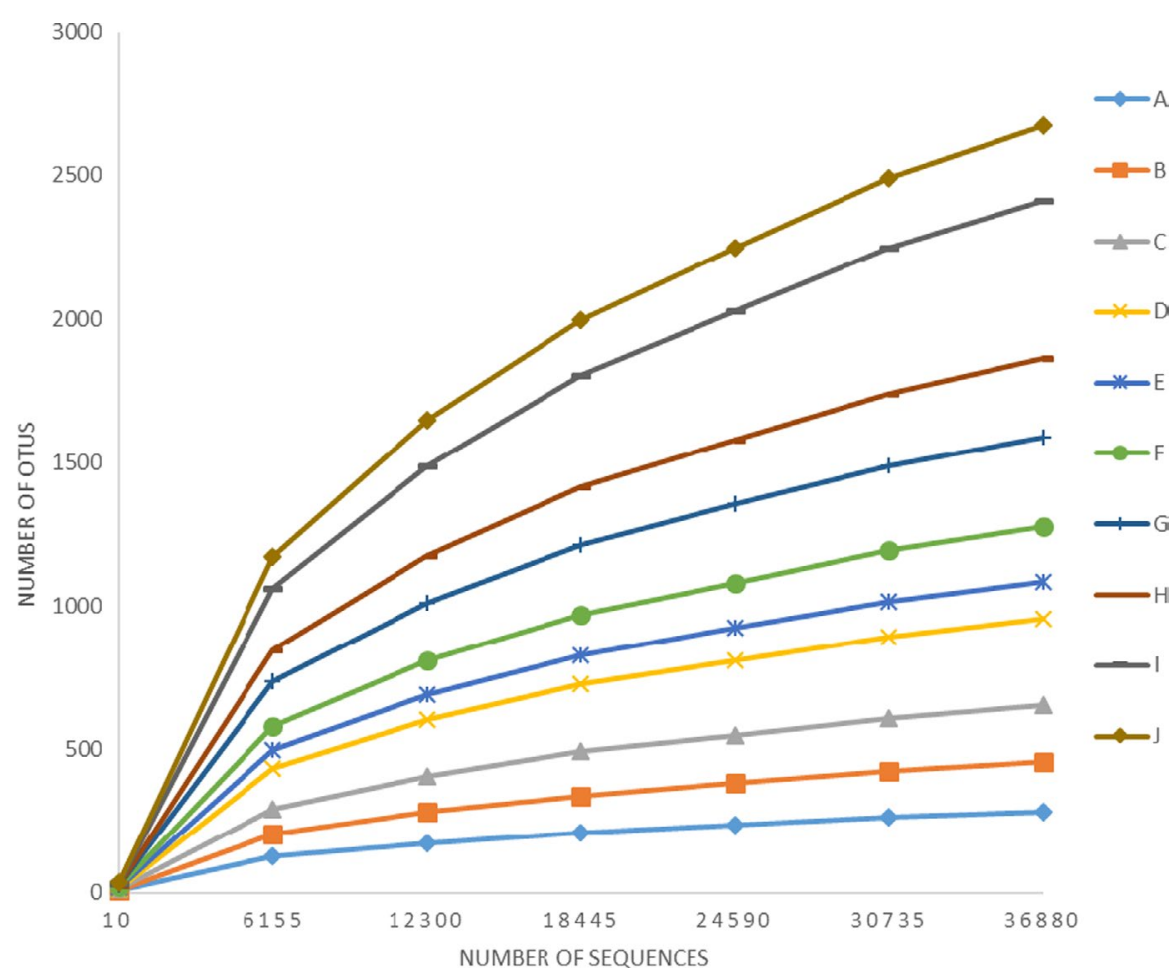

FIGURE 1 Rarefaction curves showing the observed number of operational taxonomic units (OTUs) at a genetic distance of $3 \%$ in the different larval samples [Colour figure can be viewed at wileyonlinelibrary.com]

level. The abundance of 10 major bacterial groups in each taxonomic category is presented in Table S3

A total of 37 bacterial phyla were detected in our samples. Among the phyla, Proteobacteria was the most dominant group followed by
Firmicutes and Bacteroidetes. Reads belonging to Euryarchaeota, Cyanobacteria, Acidobacteria, Actinobacteria, Chloroflexi, Deferribacteres, Spirochaetes and other bacteria were found to be very few $(>1 \%)$. These top ten bacteria phyla covered $99.7 \%$ of the

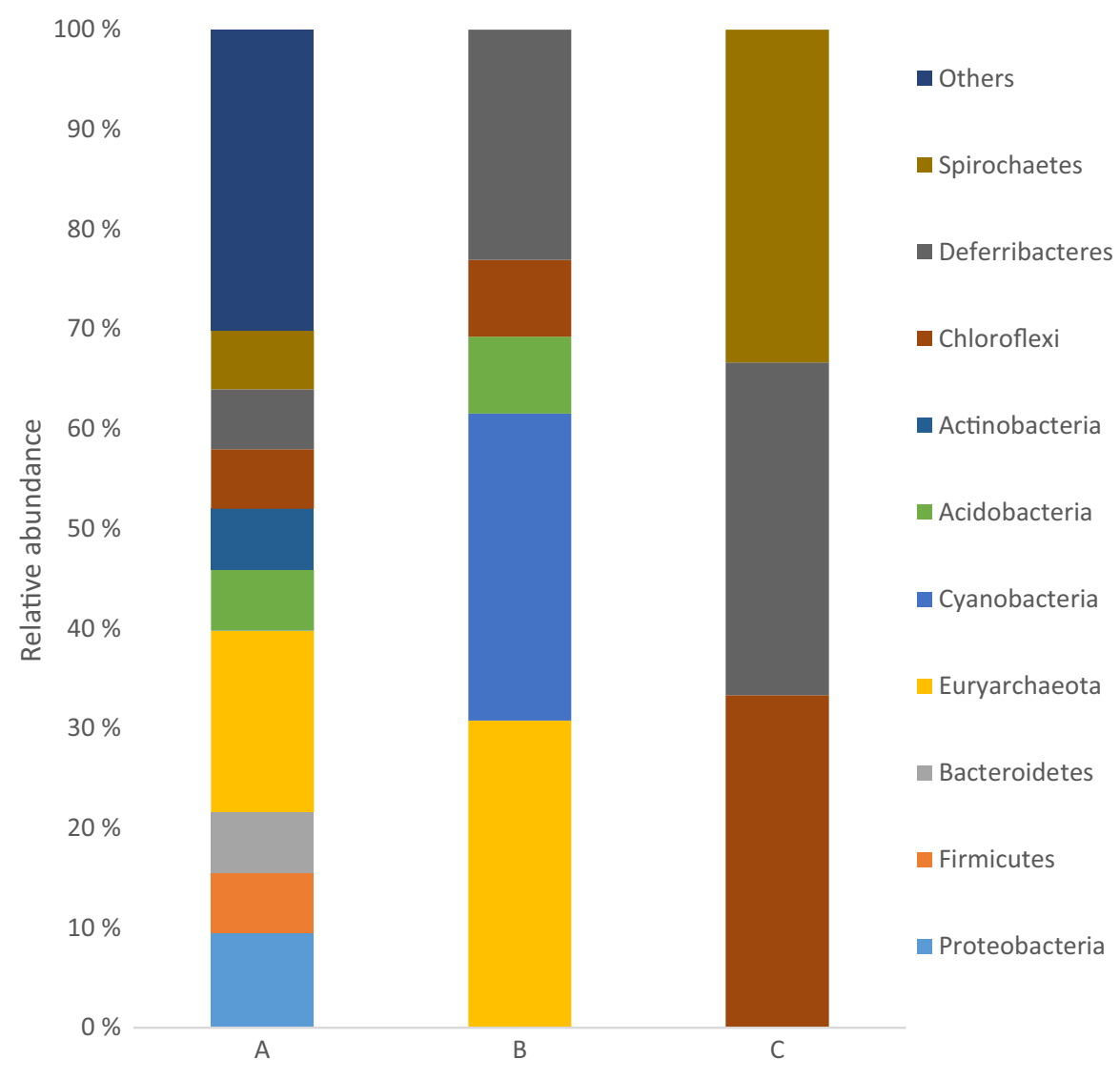

Agroecological zones
FIGURE 2 The distribution of sequences of bacterial $16 \mathrm{~S}$ rRNA gene at the phylum level (top 10) of samples from different agroecological regions. ( $A$ = south-east; $B=$ south-west; $\mathrm{C}=$ north) [Colour figure can be viewed at wileyonlinelibrary.com] 
whole bacteria phyla, and other bacteria phyla were $0.3 \%$. There were no significant differences $(p>05)$ in relative abundance of bacteria phyla among the individual larval samples (Figure S1). The relative abundance of bacteria phyla of sample groups from different agroecological zones (south-east, southwest and north) also showed no significant differences among the groups. However, the samples from southeast region were found to be dominated by higher number of bacteria phyla than samples from other regions. Samples from the north region were dominated by only three bacteria phyla namely Chloroflexi, Deferribacteres and Spirochaetes (Figure 2). The distribution of bacteria phyla of individual larvae from different locations is shown in Figure 3. The relative abundance of bacteria order was significantly different in two members: Acidobacteriales and Aeromandales with $p$ values (.026 and .045), respectively. A total of 145 bacterial families were observed in the samples with only Acidobacteriaceae ( $p=.025$ ) showing significant difference among the individual samples. At the genus level, 285 bacterial genera were present in our samples. The top 10 members of the group include Klebsiella, Enterococcus, Acinetobacter, Enterobacter, Myroides, Sphingomonas, Comamonas, Sphingobacterium, Pseudomonas and Clostridium_sensu_ stricto_5. Klebsiella was the most dominant bacterial genus followed by Enterococcus, Acinetobacter, Enterobacter and Myroides. The proportion of Pseudomonas and Clostridium_sensu_stricto_5 was $<1 \%$ each, and these top members of the genera constituted $93.37 \%$ of the whole genera, while other genera was $6.67 \%$. The lesser members of the bacteria genera among the top 20 were 12 including Pseudomonas, Clostridium_sensu_stricto_5, Delftia, unidentified_Chloroplast, Chryseobacterium, Vagococcus, Paenibacillus, Erwinia, Rhizobium, Sporosarcina, Leucobacter and Faecalibaculum, and their individual representation was $>1 \%$ each. At genus level, the relative abundance of several genera showed no significant differences $(p>.05)$ among the individual larva samples as well as in groups from different geographical regions. Only two members of the genera Novosphingobium and Pedobacter differed significantly between the individual larva samples with $p$ values of .025 and .037 , respectively (Figure S2). The relative abundance of bacteria genera among sample groups was present in similar pattern with the bacteria phyla (Figure 4).

\subsection{Domain Archaea}

The domain archaea were represented by four phyla, three classes, four orders, seven families and seven genera (Table 3). Euryarchaeota (72.22\%) was the most dominant phylum followed by Bathyarchaeota (11.11\%). At the class level, Methanomicrobia (57.14\%) was the most dominant order followed by Thermoplasmata (14.29\%). Methanomicrobiales (42.85) was the dominant order, while Methanosaeta and Methanolinea with both $25 \%$ were leading at the genus level.

\subsection{Comparisons of bacteria biota of S. frugiperda from previous studies and our study}

The major dominant bacteria genera reported from various authors on the gut of $S$. frugiperda is presented in Table 4.

\section{4 | DISCUSSION}

This study revealed that the microbiome of the fall armyworm S. frugiperda larvae were dominated by Proteobacteria followed by Firmicutes at the phylum level. This observation is in line with the earlier reports on the gut bacteria biota of other lepidopteran insects such as in European Corn Borer Ostrinia nubilalis (Belda et al., 2011), Diamondback Moth, Plutella xylostella (L.) (Ramya, Venkatesan, Srinivasa Murthy, Jalali, \& Verghese, 2016; Xia et al., 2013,2017), the African maize stem borer Busseola fusca (F.) (Snyman, Gupta, Bezuidenhout, Claassens, \& van den Berg, 2016), the Spruce Budworm (Choristoneura fumiferana) (Landry, Comeau, Derome, Cusson, \& Levesque, 2015), Pine processionary moth, Thaumetopoea pytiocampa (Denis \&Schiff.) (Strano, Malacrinò, Campolo, \& Palmeri, 2018), Silkworm Bombyx mori (Chen et al., 2018) and S. frugiperda (Gichuhi et al., 2020).

A recent review that compared microbiota studies of 30 lepidopteran species found that the most dominant phylum across
FIGURE 3 Principal component analysis (PCA) of bacterial communities in Spodoptera frugiperda individual larval samples from different locations based on the relative abundance of bacterial genera. Symbol ' $\bullet$ ' represents bacterial phylum

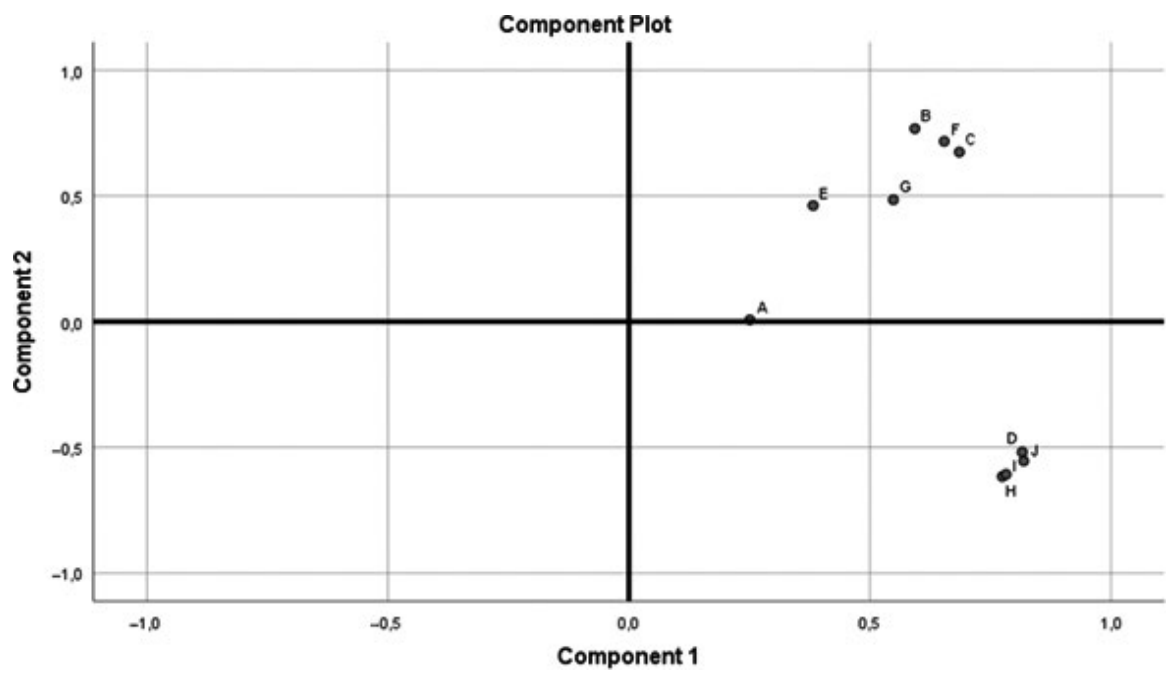




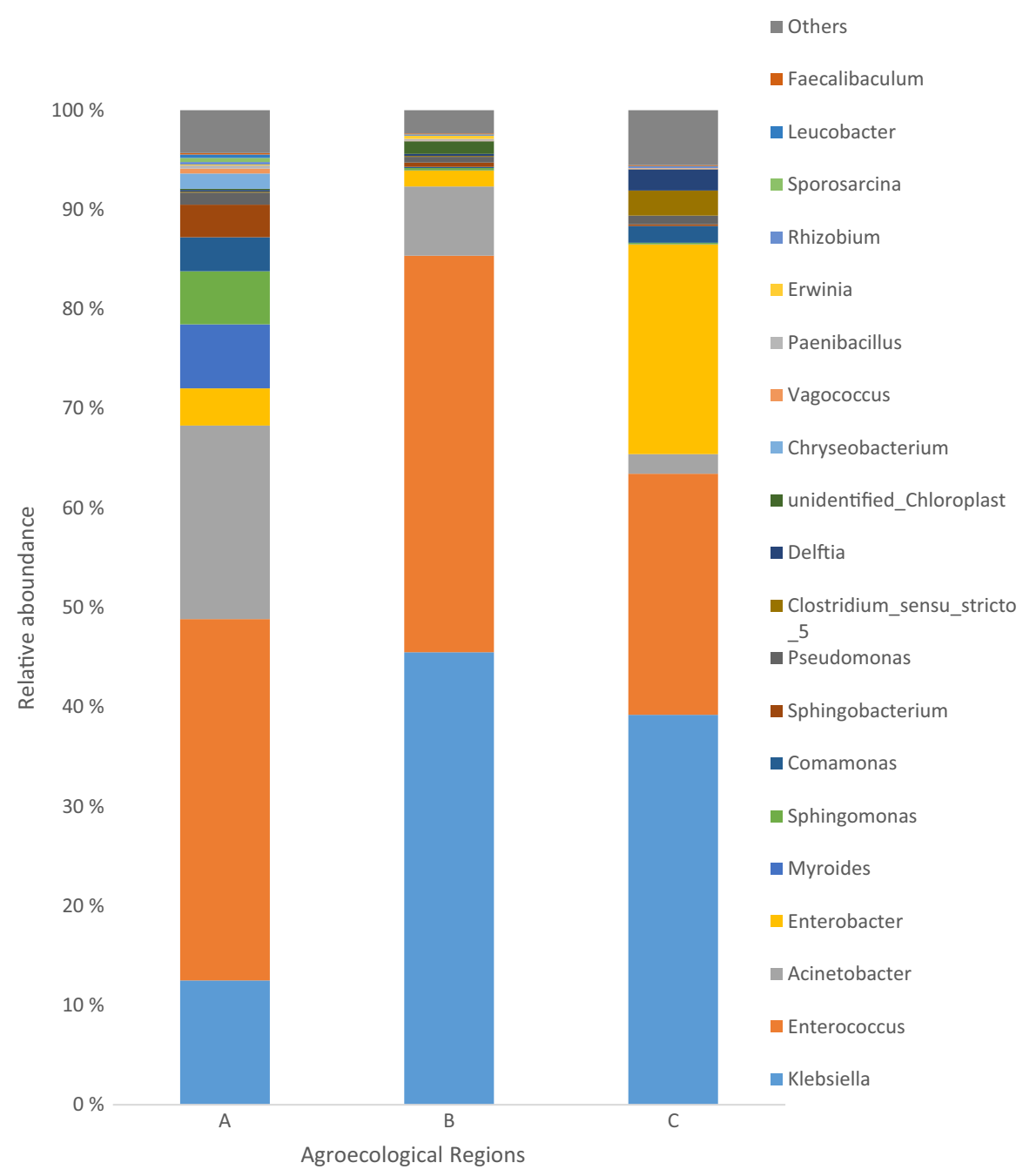

FIGURE 4 The distribution of fractional sequences of bacterial $16 \mathrm{~S}$ rRNA gene at the genus level (top 20) from different agroecological regions ( $A$ = south-east; $B$ = south-west; $\mathrm{C}=$ north) [Colour figure can be viewed at wileyonlinelibrary.com] species was Proteobacteria within the family Enterobacteriaceae (Voirol et al., 2018). However, recent studies using high-throughput sequencing (NGS) of $16 \mathrm{~S}$ rDNA to analyse the gut microbiota of late-instar field-captured $H$. armigera larvae revealed that Actinobacteria was the dominant phylum followed by Proteobacteria and Firmicutes (Ranjith, ManiChellappan, Harish, Girija, \& Nazeem, 2016) and S. frugiperda (Rozadilla et al., 2020). Another NGS study of the late-instar of the gut microbiota in S. littoralis found that Firmicutes was the most abundant phylum, followed by Proteobacteria (Chen et al., 2016; Shao, Arias-Cordero, Guo, Bartram, \& Boland, 2014).

Four bacteria genera, Enterococcus, Pseudomonas, Delftia and Serratia, observed in this study have previously been isolated from S. frugiperda (Almeida, Moraes, Trigo, Omoto, \& Cônsoli, 2017); Acevedo et al., 2017; Gichuhi et al., 2020). Additionally, Staphylococcus, Microbacterium and Arthrobacter recorded were previously isolated from S. frugiperda in Brazil (Almeida et al., 2017). Other isolates documented in this study such as Enterobacter and Klebsiella have been previously identified in oral secretions of $S$. frugiperda in Pennsylvania, USA (Acevedo et al., 2017).

In this study, Klebsiella (Proteobacteria) was the most dominant bacteria genera followed by Enterococcus in the gut of S. frugiperda.
These results support the recent report by Acevedo et al. (2017) who found Klebsiella and Enterococcus in S. frugiperda larvae but not as the predominant members of the bacteria genera. Klebsiella sp. was also reported to be prominent in the DNA data set of adult S. littoralis (Chen et al., 2016). However, Gichuhi et al. (2020) did not report the presence of Klebsiella in S. frugiperda rather recorded high proportion of Enterococcus in two larval samples from Nigeria in Kenya. Other authors also documented high relative abundances of Enterococcus and unclassified Enterobacteriaceae in the United States (Jones, Mason, Felton, \& Hoover, 2019). Members of these genera are widespread in nature and have been previously isolated from guts of other insects such as Cotton Leaf worm, Spodoptera littoralis (Shao et al., 2014) and larvae of Sugarcane borer D. saccharalis (Dantur, Enrique, Welin, \& Castagnaro, 2015). Enterococcus and Klebsiella were also shown to be abundantly present in the gut of grasshoppers (Stoops et al., 2016).

Interestingly, Serratia, Bacillus, Pseudomonas and Clostridium species, which have been reported to have insecticidal (entomopathogenic) properties (Castagnola \& Stock, 2014), were also documented. These findings are in agreement with the recent report by Gichuhi et al. (2020) on the occurrence of the same bacteria groups in S. frugipeda in their study. 


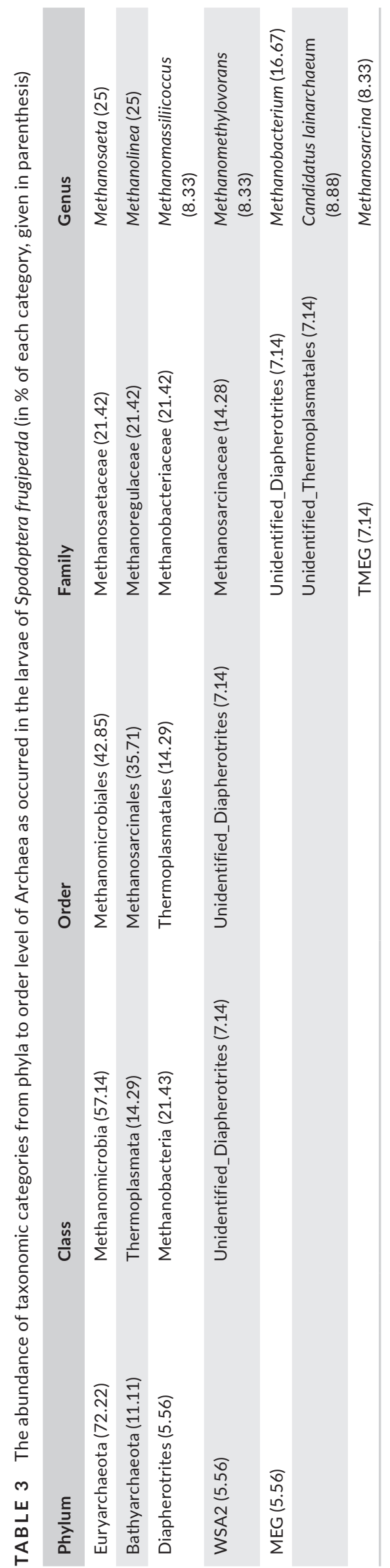

The presence of Arthrobacter woluwensis (Actinobacteria) in S. frugiperda larvae is in line with earlier reports on other lepidopteran insects. Arthrobacter ilicis (Actinobacteria) was found in the larval gut of Helicoverpa armigera in India (Ranjith et al., 2016). Similarly, analysis of $16 \mathrm{~S}$ rDNA of gut bacterial community in oriental army worm, Mythmina seperata, revealed the presence of the Arthrobacter species (He, Nan, Zhang, \& Li, 2013). Occurrences of these bacteria in the gut of insects may aid in eliciting the binding of synthetic insecticide molecules (organophosphorus and carbamates groups) to the enzyme and prevent activity of the insecticides on the target organisms (Ranjith et al., 2016).

The gut bacteria Clostridia sp. and Microbacterium identified in S. frugiperda are associated with the breakdown of plant cell wall components such as cellulose and xylan. Similarly, Acidobacterium sp., Clostridia sp., Microbacterium sp., Flavobacter johnsoni and Thermobia sp. found in $\mathrm{H}$. armigera gut have been reported to be involved in digestion of cellulose in the gut of other insects (Castaneda \& Mallol, 2013; Huang, Sheng, \& Zhang, 2012; Ranjith et al., 2016). Also, Pseudomonas sp. and Clostridia sp. detected in our study have been reported to be responsible for degradation lignocelluloses in wood-feeding beetles and termites (Lynd, Weimer, van Zyl, \& Pretorius, 2002; Rizzi et al., 2013). The Candidatus sp. detected in the gut of $S$. frugiperda is capable of providing essential amino acids to insects flourishing on nutrient-deficient diets (Moran \& Mira, 2001; Nikoh, Hosokawa, Oshima, Hattori, \& Fukatsu, 2011). Thus, the associations were considered beneficial to the $S$. frugiperda in the improvement of the nutrient status of their diet. In this study, we identified Burkholderia bacteria, which are capable of detoxifying pesticides as well as Enterococcus sp. and Rhodococcus sp. that functions in detoxifying plant toxins. Similarly, Ranjith et al. (2016) reported that Burkholderia, Enterococcus sp. and Rhodococcus sp. were detected in the gut of $\mathrm{H}$. armigera.

We observed similarities as well as variations in our studies from the reports of previous work on microbiome of $S$. frugiperda from different countries. From the five studies, so far reported in different countries (Brazil, USA, Kenya, Argentina and Nigeria) Enterococcus was persistent in gut of the $S$. frugiperda larvae. The genus Pseudomonas was recorded in four countries (Brazil, USA, Kenya and Nigeria), while Enterobacter was persistent in studies at three different countries (USA, Argentina and Nigeria) Similarly, Chryseobacterium, Comamonas and Sphingobacterium were recorded in three countries (USA, Kenya and Nigeria). The composition of these bacteria genera found in the gut of S. frugiperda larvae varied in samples from different countries. These variations indicate that environment could be a driving force in the composition of bacteria as seen from the previous report on the bacteria diversity in the gut of S. frugiperda. Andersen, Chapman, and Artz (2013) also reported that environmental conditions may be a stronger driver of microbial community composition. The variation in the bacteria composition in the gut of $S$. frugiperda larvae as seen from the previous studies could also be attributed to different maize genotypes, geographical locations and different developmental stage of larvae. However, the observed insignificant differences in the relative abundance and 
TA B LE 4 Previous report on dominant bacteria genera of Spodoptera frugiperda in different countries

\begin{tabular}{|c|c|c|c|c|c|}
\hline $\begin{array}{l}\text { Acevedo } \\
\text { et al. (2017) (USA) }\end{array}$ & $\begin{array}{l}\text { Almeida et al. (2017) } \\
\text { (Brazil) }\end{array}$ & $\begin{array}{l}\text { Jones et al. (2019) } \\
\text { (USA) }\end{array}$ & $\begin{array}{l}\text { Gichuhi et al. (2020) } \\
\text { (Kenya) }\end{array}$ & $\begin{array}{l}\text { Rozadilla et al. (2020) } \\
\text { Argentina }\end{array}$ & $\begin{array}{l}\text { Current study } \\
\text { (Nigeria) }\end{array}$ \\
\hline Enterobacter & Arthrobacter & Acinetobacter & Achromobacter & Enterobacter & Acinetobacter \\
\hline Pantoea & Enterococcus & Arthrobacter & Aeromonas & Janibacter & $\begin{array}{l}\text { Clostridium_ } \\
\text { sensu_stricto_5 }\end{array}$ \\
\hline \multirow{11}{*}{ Serratia } & Pseudomonas & Comamonas & Citrobacter & Rubrobacter & Enterobacter \\
\hline & Staphylococcus & Enterococcus & Comamonas & Vibrio & Enterococcus \\
\hline & & Flavobacterium & Cutibacterium & Xanthomonadaceae & Erwinia \\
\hline & & Ochrobactrum & Morganella & & Paenibacillus \\
\hline & & Pseudomonas & Ochrobactrum & & Pseudomonas \\
\hline & & Ralstonia & Pseudomonas & & Bradyrhizobium \\
\hline & & Rhizobium & Serratia & & Rhizobium \\
\hline & & Sphingobacterium & Sphingobacterium & & Sphingobacterium \\
\hline & & Sphingomonas & Stenotrophomonas & & Sphingomonas \\
\hline & & $\begin{array}{l}\text { Unclassified } \\
\text { Enterobacteriaceae }\end{array}$ & & & Sporosarcina \\
\hline & & $\begin{array}{l}\text { Unclassified } \\
\text { Enterobacteriaceae }\end{array}$ & & & $\begin{array}{l}\text { Unidentified_ } \\
\text { Chloroplast }\end{array}$ \\
\hline
\end{tabular}

Note: The most commonly represented bacteria genera in different studies are highlighted with the same colour across the rows.

microbial diversity of samples from different agroecological regions in this study could be attributed to the unvarying developmental stage of the larvae used, the same maize host genotype and larvae enclosure within the maize whorls at the point of sampling/ collection that may limit the effects of the environments.

The study by Acevedo et al. (2017) in the United States revealed five major bacteria genera using culture-dependent methods, while in Brazil the gut of $S$. frugiperda revealed eight major bacterial genera that are resistant to different insecticides based on 165 rDNA sequence similarities obtained from heuristic search against sequences in NCBI and EzTaxon-e databases (Almeida et al., 2017). Another study in the United States and Puerto Rico reported 20 major bacteria genera to be associated with the gut of $S$. frugiperda larvae using bacterial 16 S rRNA sequencing (Jones et al., 2019). Similarly, a study in Kenya using NGS reported 19 major bacteria genera in the gut of S. frugiperda (Gichuhi et al., 2020). The fifth report on S. frugiperda Argentina using high-throughput pyrosequencing of $16 \mathrm{~S}$ rDNA reported 10 major bacteria genera with other non-bacterial group (Rozadilla et al. (2020). In the present study, 20 major bacterial genera were documented. The variations in microbial diversity of S. frugiperda as shown in previous studies could also be attributed to the different molecular tools used by various authors. Prior studies have shown that molecular methods offer powerful tools for detecting bacterial and fungal structure and diversity in ecological samples and appraising the response of microbes to ecological changes (Allison \& Martiny, 2008; Weedon et al., 2012).

This study revealed that Archaea are present in S. frugiperda larvae. This finding corroborates the recent report by Rozadilla et al. (2020) who also detected the presence of archaea in the gut of $S$. frugiperda larvae using high-throughput pyrosequencing of $16 \mathrm{~S}$ rDNA, and it represented a high proportion of the metabolically active gut microbiota in S. frugiperda. Archaea have been revealed through metagenomic studies to be very diverse and prolific, and they play vital roles in nitrogen cycling in soils (Bates et al., 2011; Edwards et al., 2015; Siles, Öhlinger, Cajthaml, Kistler, \& Margesin, 2018; Secil, Sevim, Demirbag, $\&$ Demir, 2012). There is insufficient information on the roles they play in their host (Gurung et al., 2019) although it has been suggested that they could affect plants (Taffner et al., 2018). In this study, Euryarchaeota was the most dominant archaea phylum followed by Bathyarchaeota in the gut of S. frugiperda. On the contrary, Rozadilla et al. (2020) reported only uncultured Crenarchaeota in the gut of S. frugiperda in their own study. However, phylum Euryarchaeota 
has been reported in the hindguts of beetles, cockroaches, termites and millipedes (Brune, 2009; Egert et al., 2005; Hara, Shinzato, Seo, Oshima, \& Yamagishi, 2002; Shinzato, Matsumoto, Yamaoka, Oshima, \& Yamagishi, 1999; Šustr, Chroňáková, Semanová, Tajovský, \& Šimek, 2014; Tinker \& Ottesen, 2016). Similarly, shotgun metagenomic analysis of the gut of diamondback moth Plutella xylostella larvae revealed Euryarchaeota DNA in very low proportions (Xia et al., 2017).

In conclusion, the bacterial communities in S. frugiperda larval samples collected randomly from different locations in Nigeria were unravelled with aid of NGS sequencing. Significant differences and resemblances across samples and in relation to other studies on this species were observed. Bacteria were the dominant microbiota in the gut of $S$. frugipeda, while archaea were relatively a minor component of the microbiota community. Among the bacterial community, the most dominant group was Proteobacteria. Notable was the presence of insecticidal toxin-producing bacteria (entomopathogenic) in the gut of S. frugiperda. Geographical location did not influence the larval microbiome of $S$. frugiperda in this study. Characterizing the microbial diversity of this pest species in Nigeria is a significant step towards the exploration of novel, cost-effective biological-based management strategies. Further studies to analyse more samples from different environment and food sources to determine the significance of the taxa found in this study and their functional roles are ongoing.

\section{ACKNOWLEDGEMENTS}

We are grateful to Schlumberger Faculty for the Future Foundation (SFFTF) for funding this research, University of Helsinki, Finland, for the Laboratory Facilities provided for study and Forestry Research Institute of Nigeria for their support towards making this study a reality.

\section{CONFLICT OF INTEREST}

The authors declare no conflicts of interest.

\section{AUTHOR CONTRIBUTION}

JAU and FOA conceived the research. JAU and ML conducted the experiments. JAU and FOA contributed material. JAU and HS analysed data and conducted statistical analyses. JAU wrote the manuscript. JAU secured funding. All authors read and approved the manuscript.

\section{DATA AVAILABILITY STATEMENT}

The data that support the findings of this study are openly available in Tables S1-S3.

\section{ORCID}

Juliana Amaka Ugwu (iD https://orcid.org/0000-0003-1862-6864

Mengxia Liu iD https://orcid.org/0000-0003-2069-9595

Fred O. Asiegbu iD https://orcid.org/0000-0003-0223-7194

\section{REFERENCES}

Acevedo, F. E., Peiffer, M., Tan, C.-W., Stanley, B. A., Stanley, A., Wang, J., ... Felton, G. (2017). Fall armyworm-associated gut bacteria modulate plant defense responses. Molecular Plant-Microbe Interactions, 30(2), 127-137. https://doi.org/10.1094/MPMI-11-16-0240-R

Allison, S. D., \& Martiny, J. B. H. (2008). Resistance, resilience, and redundancy in microbial communities. Proceedings of the National Academy of Sciences of the United States of America, 105, 11512-11519. https:// doi.org/10.1073/pnas.0801925105

Andersen, R., Chapman, S. J., \& Artz, R. R. E. (2013). Microbial communities in natural and disturbed peatlands: A review. Soil Biology and Biochemistry, 57, 979-994. https://doi.org/10.1016/j.soilb io.2012.10.003

Arora, A. K., \& Douglas, A. E. (2017). Hype or opportunity? Using microbial symbionts in novel strategies for insect pest control. Journal of Insect Physiology, 103, 10-17. https://doi.org/10.1016/j.jinsp hys.2017.09.011

Bates, S. T., Berg-Lyons, D., Caporaso, J. G., Walters, W. A., Knight, R., \& Fierer, N. (2011). Examining the global distribution of dominant archaeal populations in soil. ISME Journal, 5(5), 908-917. https://doi. org/10.1038/ismej.2010.171

Beck, J. J., \& Vannette, R. L. (2017). Harnessing insect-microbe chemical communications to control insect pests of agricultural systems. Journal of Agricultural and Food Chemistry, 65(1), 23-28. https://doi. org/10.1021/acs.jafc.6b04298

Belda, E., Pedrola, L., Peretó, J., Martínez-Blanch, J. F., Montagud, A., Navarro, E., ... Porcar, M. (2011). Microbial diversity in the midguts of field and lab-reared populations of the European corn borer Ostrinia nubilalis. PLoS One, 6(6), e21751. https://doi.org/10.1371/journ al.pone.0021751

Bokulich, N. A., Subramanian, S., Faith, J. J., Gevers, D., Gordon, J. I., Knight, R., ... Caporaso, J. G. (2013). Quality-filtering vastly improves diversity estimates from Illumina amplicon sequencing. Nature Methods, 10(1), 57-59. https://doi.org/10.1038/nmeth.2276

Brune, A. (2009). Methanogenesis in the digestive tracts of insects. In K. N. Timmis (Ed.), Handbook of hydrocarbon and lipid microbiology (pp. 707-728). Heidelberg, Germany: Springer.

CABI (2018). Invasives species compendium. Retrieved from www.cabi. org/isc/fallarmyworm

Caporaso, J. G., Kuczynski, J., Stombaugh, J., Bittinger, K., Bushman, F. D., Costello, E. K., ... Knight, R. (2010). QIIME allows analysis of high-throughput community sequencing data. Nature Methods, 7(5), 335-336. https://doi.org/10.1038/nmeth.f.303

Carvalho, R. A., Omoto, C., Field, L. M., Williamson, M. S., \& Bass, C. (2013). Investigating the molecular mechanisms of organophosphate and pyrethroid resistance in the fall armyworm Spodoptera frugiperda. PLoS One, 8(4), e62268. https://doi.org/10.1371/journ al.pone. 0062268

Casmuz, A., Juarez, M. L., Socias, M. G., Murua, M. G., Prieto, S., Medina, S., ... Gastaminza, G. (2010). Review of the host plants of fall armyworm, Spodoptera frugiperda (Lepidoptera: Noctuidae). Revista De La Sociedad Entomologica Argentina, 69(3-4), 209-231.

Castagnola, A., \& Stock, S. P. (2014). Common virulence factors and tissue targets of entomopathogenic bacteria for biological control of Lepidopteran pests. Insects, 5(1), 139-166. https://doi.org/10.3390/ insects5010139

Castaneda, R. E. Q., \& Mallol, J. L. F. (2013). Hydrolysis of biomass mediated by cellulases for the production of sugars. In A. Chandel, \& S. S. Da Silva (Eds.), Sustainable degradation of lignocellulosic biomass - Techniques, applications and commercialization (pp. 119-152). Norderstedt, Germany: Books on Demand (BoD).

Chandrasena, D. I., Signorini, A. M., Abratti, G., Storer, N. P., Olaciregui, M. L., Alves, A. P., \& Pilcher, C. D. (2018). Characterization of field evolved resistance to Bacillus thuringiensis-derived Cry1F $\delta$-endotoxin in Spodoptera frugiperda populations from Argentina. Pest Management Science, 74(3), 746-754. https://doi.org/10.1002/ps.4776

Chao, A. (1984). Nonparametric estimation of the number of classes in a population. Scandinavian Journal of Statistics, 11, 265-270. 
Chao, A., \& Lee, S. M. (1992). Estimating the number of classes via sample coverage. Journal of American Statistical Association, 87(417), 210217. https://doi.org/10.1080/01621459.1992.10475194

Chen, B., Du, K., Sun, C., Vimalanathan, A., Liang, X., Li, Y., ... Shao, Y. (2018). Gut bacterial and fungal communities of the domesticated silkworm (Bombyx mori) and wild mulberry-feeding relatives. The ISME Journal, 12(9), 2252-2262. https://doi.org/10.1038/s4139 6-018-0174-1

Chen, B., Teh, B.-S., Sun, C., Hu, S., Lu, X., Boland, W., \& Shao, Y. (2016). Biodiversity and activity of the gut microbiota across the life history of the insect herbivore Spodoptera littoralis. Scientific Reports, 6(1), 29505. https://doi.org/10.1038/srep29505

Chung, S. H., Rosa, C., Scully, E. D., Peiffer, M., Tooker, J. F., Hoover, K., ... Felton, G. W. (2013). Herbivore exploits orally secreted bacteria to suppress plant defenses. Proceedings of the National Academy of Sciences of the United States of America, 110(39), 15728-15733. https://doi.org/10.1073/pnas.1308867110

Cock, M. J., Beseh, P. K., Buddie, A. G., Cafa, G., \& Crozier, J. (2017). Molecular methods to detect Spodoptera frugiperda in Ghana, and implications for monitoring the spread of invasive species in developing countries. Scientific Reports, 7(1), 4103.

Cock, P. J. A., Fields, C. J., Goto, N., Heuer, M. L., \& Rice, P. M. (2010). The Sanger FASTQ file format for sequences with quality scores, and the Solexa/Illumina FASTQ variants. Nucleic Acids Research, 38(6), 1767-1771. https://doi.org/10.1093/nar/gkp1137

Crotti, E., Balloi, A., Hamdi, C., Sansonno, L., Marzorati, M., Gonella, E., ... Daffonchio, D. (2012). Microbial symbionts: A resource for the management of insect-related problems: Microbial Resource Management applied to insects. Microbial Biotechnology, 5(3), 307317. https://doi.org/10.1111/j.1751-7915.2011.00312.x

Dantur, K. I., Enrique, R., Welin, B., \& Castagnaro, A. P. (2015). Isolation of cellulolytic bacteria from the intestine of Diatraea saccharalis larvae and evaluation of their capacity to degrade sugarcane biomass. AMB Express, 5(1), 15. https://doi.org/10.1186/s1356 8-015-0101-z

Day, R., Abrahams, P., Bateman, M., Beale, T., Clottey, V., Cock, M., ... Witt, A. (2017). Fall Armyworm: Impacts and Implications for Africa. Outlooks on Pest Management, 28(5), 196-201. https://doi. org/10.1564/v28_oct_02

de Almeida, L. G., de Moraes, L. A. B., Trigo, J. R., Omoto, C., \& Cônsoli, F. L. (2017). The gut microbiota of insecticide-resistant insects houses insecticide-degrading bacteria: A potential source for biotechnological exploitation. PLoS One, 12(3), e0174754. https://doi.org/10.1371/ journal.pone.0174754

Douglas, A. E. (2015). Multiorganismal insects: Diversity and function of resident microorganisms. Annual Review of Entomology, 60(1), 17-34. https://doi.org/10.1146/annurev-ento-010814-020822

Edgar, R. C. (2013). UPARSE: Highly accurate OTU sequences from microbial amplicon reads. Nature Methods, 10(10), 996-998. https://doi. org/10.1038/nmeth.2604

Edgar, R. C., Haas, B. J., Clemente, J. C., Quince, C., \& Knight, R. (2011). UCHIME improves sensitivity and speed of chimera detection. Bioinformatics, 27(16), 2194-2200. https://doi.org/10.1093/bioin formatics/btr381

Edwards, J., Johnson, C., Santos-Medellín, C., Lurie, E., Podishetty, N. K., Bhatnagar, S., \& Sundaresan, V. (2015). Structure, variation, and assembly of the root-associated microbiomes of rice. Proceedings of the National Academy of Sciences of the United States of America, 112(8), E911-E920. https://doi.org/10.1073/pnas.1414592112

Egert, M., Stingl, U., Bruun, L. D., Pommerenke, B., Brune, A., \& Friedrich, M. W. (2005). Structure and topology of microbial communities in the major gut compartments of Melolontha melolontha larvae (Coleoptera: Scarabaeidae). Applied and Environmental Microbiology, 71(8), 45564566. https://doi.org/10.1128/AEM.71.8.4556-4566.2005
Engel, P., \& Moran, N. A. (2013). The gut microbiota of insects-Diversity in structure and function. FEMS Microbiology Reviews, 37, 699-735. https://doi.org/10.1111/1574-6976.12025

FAO (2018). Integrated management of the fall armyworm on maize. A guide for farmer field schools in Africa. Rome, Italy: FAO.

Farias, J. R., Andow, D. A., Horikoshi, R. J., Sorgatto, R. J., Fresia, P., dos Santos, A. C., \& Omoto, C. (2014). Field-evolved resistance to Cry1F maize by Spodoptera frugiperda (Lepidoptera: Noctuidae) in Brazil. Crop Protection, 64, 150-158. https://doi.org/10.1016/j. cropro.2014.06.019

Ferrari, J., Vavre, F., \& Lyon, D. (2011). Bacterial symbionts in insects or the story of communities affecting communities. Philosophical Transactions of the Royal Society B: Biological Sciences, 366(1569), 1389-1400. https://doi.org/10.1098/rstb.2010.0226

Gichuhi, J., Sevgan, S., Khamis, F., Van den Berg, J., du Plessis, H., Ekesi, S., \& Herren, J. K. (2020). Diversity of fall armyworm, Spodoptera frugiperda and their gut bacterial community in Kenya. PeerJ, 8, e8701. https://doi.org/10.7717/peerj.8701

Gurung, K., Wertheim, B., \& Falcao Salles, J. (2019). The microbiome of pest insects: It is not just bacteria. Entomologia Experimentalis Et Applicata, 167(3), 156-170. https://doi.org/10.1111/eea.12768

Haas, B. J., Gevers, D., Earl, A. M., Feldgarden, M., Ward, D. V., Giannoukos, G., ... Birren, B. W. (2011). Chimeric 16S rRNA sequence formation and detection in Sanger and 454-pyrosequenced PCR amplicons. Genome Research, 21(3), 494-504. https://doi.org/10.1101/ gr.112730.110

Hammer, T. J., \& Bowers, M. D. (2015). Gut microbes may facilitate insect herbivory of chemically defended plants. Oecologia, 179(1), 1-14. https://doi.org/10.1007/s00442-015-3327-1

Hammer, T. J., Janzen, D. H., Hallwachs, W., Jaffe, S. P., \& Fierer, N. (2017). Caterpillars lack a resident gut microbiome. Proceedings of the National Academy of Sciences of the United States of America, 114(36), 9641-9646. https://doi.org/10.1073/pnas.1707186114

Hara, K., Shinzato, N., Seo, M., Oshima, T., \& Yamagishi, A. (2002). Phylogenetic analysis of symbiotic archaea living in the gut of $x y-$ lophagous cockroaches. Microbes and Environments, 17(4), 185-190. https://doi.org/10.1264/jsme2.17.185

He, C., Nan, X., Zhang, Z., \& Li, M. (2013). Composition and diversity analysis of the gut bacterial community of the oriental armyworm, Mythimna separata, determined by culture-independent and culture-dependent techniques. Journal of Insect Science, 13(165), 1-11. https://doi.org/10.1673/031.013.16501

Huang, F., Qureshi, J. A., Meagher, R. L., Reisig, D. D., Head, G. P., Andow, D. A., \& Dangal, V. (2014). Cry1F resistance in fall armyworm Spodoptera frugiperda: Single gene versus pyramided Bt maize. PLoS One, 9(11), e112958. https://doi.org/10.1371/journal.pone.0112958

Huang, S., Sheng, P., \& Zhang, H. (2012). Isolation and identification of cellulolytic bacteria from the gut of Holotrichia parallela Larvae (Coleoptera: Scarabaeidae). International Journal of Molecular Sciences, 13(3), 2563-2577. https://doi.org/10.3390/ijms13032563

Jones, A. G., Mason, C. J., Felton, G. W., \& Hoover, K. (2019). Host plant and population source drive diversity of microbial gut communities in two polyphagous insects. Scientific Reports, 9(1), 2792. https://doi. org/10.1038/s41598-019-39163-9

Kikuchi, Y., Hayatsu, M., Hosokawa, T., Nagayama, A., Tago, K., \& Fukatsu, T. (2012). Symbiont-mediated insecticide resistance. Proceedings of the National Academy of Sciences of the United States of America, 109(22), 8618-8622. https://doi.org/10.1073/ pnas.1200231109

Kim, B.-R., Shin, J., Guevarra, R. B., Lee, J. H., Kim, D. W., Seol, K.-H., ... Isaacson, R. E. (2017). Deciphering diversity indices for a better understanding of microbial communities. Journal of Microbiology and Biotechnology, 27(12), 2089-2093. https://doi.org/10.4014/ jmb.1709.09027 
Klindworth, A., Pruesse, E., Schweer, T., Peplies, J., Quast, C., Horn, M., \& Glöckner, F. O. (2013). Evaluation of general 16S ribosomal RNA gene PCR primers for classical and next-generation sequencing-based diversity studies. Nucleic Acids Research, 41, e1. https://doi. org/10.1093/nar/gks808

Landry, M., Comeau, A. M., Derome, N., Cusson, M., \& Levesque, R. C. (2015). Composition of the spruce budworm (Choristoneura fumiferana) midgut microbiota as affected by rearing conditions. PLoS One, 10(12), e0144077. https://doi.org/10.1371/journal.pone.0144077

Lynd, L. R., Weimer, P. J., van Zyl, W. H., \& Pretorius, I. S. (2002). Microbial cellulose utilization: Fundamentals and biotechnology. Microbiology and Molecular Biology Reviews, 66(4), 739. https://doi.org/10.1128/ MMBR.66.4.739.2002

Magoč, T., \& Salzberg, S. L. (2011). FLASH: Fast length adjustment of short reads to improve genome assemblies. Bioinformatics, 27(21), 2957-2963. https://doi.org/10.1093/bioinformatics/btr507

Manson, C. J., Jones, A. G., \& Felton, G. W. (2018). Co-option of microbial associates by insects and their impact on plant-folivore interactions. Plant, Cell and Environment, 42, 1078-1086. https://doi.org/10.1111/ pce. 13430

Marchesi, J. R., \& Ravel, J. (2015). The vocabulary of microbiome research: A proposal. Microbiome, 3(1). https://doi.org/10.1186/s4016 8-015-0094-5

Moran, N. A., \& Mira, A. (2001). The process of genome shrinkage in the obligate symbiont Buchnera aphidicola. Genome Biology, 2, research 0054.1. https://doi.org/10.1186/gb-2-12-research0054

Nascimento, A. R. B. D., Farias, J. R., Bernardi, D., Horikoshi, R. J., \& Omoto, C. (2016). Genetic basis of Spodoptera frugiperda (Lepidoptera: Noctuidae) resistance to the chitin synthesis inhibitor lufenuron. Pest Management Science, 72(4), 810-815.

Nikoh, N., Hosokawa, T., Oshima, K., Hattori, M., \& Fukatsu, T. (2011). Reductive evolution of bacterial genome in insect gut environment. Genome Biology and Evolution, 3, 702-714. https://doi.org/10.1093/ gbe/evr064

Omoto, C., Bernardi, O., Salmeron, E., Sorgatto, R. J., Dourado, P. M., Crivellari, A., ... Head, G. P. (2016). Field-evolved resistance to Cry1Ab maize by Spodoptera frugiperda in Brazil. Pest Management Science, 72(9), 1727-1736. https://doi.org/10.1002/ps.4201

Perilla-Henao, L. M., \& Casteel, C. L. (2016). Vector-borne bacterial plant pathogens: Interactions with hemipteran insects and plants. Frontiers in Plant Science, 7, 1163. https://doi.org/10.3389/fpls.2016.01163

Pogue, M. G. (2002). A world revision of the genus Spodoptera guenée (Lepidoptera: Noctuidae) (vol. 43, 1-222). Memoirs of the American Entomological Society. Lanham, MD: American Entomological Society.

Quast, C., Pruesse, E., Yilmaz, P., Gerken, J., Schweer, T., Yarza, P., ... Glöckner, F. O. (2012). The SILVA ribosomal RNA gene database project: Improved data processing and web-based tools. Nucleic Acids Research, 41(D1), D590-D596. https://doi.org/10.1093/nar/gks1219

Ram, M. (2019). Fall Armyworm attack: Deadliest pest epidemic grips. Down to Earth, India. Retrieved from https://www.downtoearth.org. in/news/agriculture/fallarmyworm-attack-deadliest-pest-epidemicgripsindia-63372

Ramya, S. L., Venkatesan, T., Srinivasa Murthy, K., Jalali, S. K., \& Verghese, A. (2016). Detection of carboxylesterase and esterase activity in culturable gut bacterial flora isolated from diamondback moth, Plutella xylostella (Linnaeus), from India and its possible role in indoxacarb degradation. Brazilian Journal of Microbiology, 47(2), 327-336. https:// doi.org/10.1016/j.bjm.2016.01.012

Ranjith, M. T., ManiChellappan, E, Harish, E. R., Girija, D., \& Nazeem, P. A. (2016). Bacterial communities associated with the gut of tomato fruit borer, Helicoverpa armigera (Hübner) (Lepidoptera: Noctuidae) based on Illumina Next-Generation Sequencing. Journal of Asia-Pacific Entomology, 19(2), 333-340. https://doi.org/10.1016/j. aspen.2016.03.007
Rizzi, A., Crotti, E., Borruso, L., Jucker, C., Lupi, D., Colombo, M., \& Daffonchio, D. (2013). Characterization of the bacterial community associated with larvae and adults of Anoplophora chinensis collected in italy by culture and culture-independent methods. BioMed Research International, 2013, 1-12. https://doi. org/10.1155/2013/420287

Rozadilla, G., Cabrera, N. A., Virla, E. G., Greco, N. M., \& McCarthy, C. B. (2020). Gut microbiota of Spodoptera frugiperda (J.E. Smith) larvae as revealed by metatranscriptomic analysis. Journal of Applied Entomology, 144, 351-363. https://doi.org/10.1111/jen.12742

Sanchis, V. (2011). From microbial sprays to insect-resistant transgenic plants: History of the biospesticide Bacillus thuringiensis. A review. Agronomy for Sustainable Development, 31(1), 217-231. https://doi. org/10.1051/agro/2010027

Secil, E., Sevim, A., Demirbag, Z., \& Demir, I. (2012). Isolation, characterization and virulence of bacteria from Ostrinia nubilalis (Lepidoptera: Pyralidae). Biologia, 67(4), 767-776.https://doi.org/10.2478/s1175 6-012-0070

Shao, Y., Arias-Cordero, E., Guo, H., Bartram, S., \& Boland, W. (2014). In vivo Pyro-SIP assessing active gut microbiota of the cotton leafworm, Spodoptera littoralis. PLoS One, 9(1), 1-13. https://doi.org/10.1371/ journal.pone.0085948

Shinzato, N., Matsumoto, T., Yamaoka, I., Oshima, T., \& Yamagishi, A. (1999). Phylogenetic diversity of symbiotic methanogens living in the hindgut of the lower termite. Applied and Environmental Microbiology, 65(2), 837-840. https://doi.org/10.1111/jen.12742

Siles, J. A., Öhlinger, B., Cajthaml, T., Kistler, E., \& Margesin, R. (2018). Characterization of soil bacterial, archaeal and fungal communities inhabiting archaeological human-impacted layers at Monte lato settlement (Sicily, Italy). Scientific Reports, 8(1), 1903. https://doi. org/10.1038/s41598-018-20347-8

Silva, D. M. D., Bueno, A. D. F., Andrade, K., Stecca, C. D. S., Neves, P. M. O. J., \& Oliveira, M. C. N. D. (2017). Biology and nutrition of Spodoptera frugiperda (Lepidoptera: Noctuidae) fed on different food sources. Scientia Agricola, 74(1), 18-31. https://doi. org/10.1590/1678-992x-2015-016

Snyman, M., Gupta, A. K., Bezuidenhout, C. C., Claassens, S., \& van den Berg, J. (2016). Gut microbiota of Busseola fusca (Lepidoptera: Noctuidae). World Journal of Microbiology and Biotechnology, 32(7), 115. https://doi.org/10.1007/s11274-016-2066-8

Stoops, J., Crauwels, S., Waud, M., Claes, J., Lievens, B., \& Van Campenhout, L. (2016). Microbial community assessment of mealworm larvae (Tenebrio molitor) and grasshoppers (Locusta migratoria migratorioides) sold for human consumption. Food Microbiology, 53, 122-127. https://doi.org/10.1016/j.fm.2015.09.010

Storer, N. P., Babcock, J. M., Schlenz, M., Meade, T., Thompson, G. D., Bing, J. W., \& Huckaba, R. M. (2010). Discovery and characterization of field resistance to Bt Maize: Spodoptera frugiperda (Lepidoptera: Noctuidae) in Puerto Rico. Journal of Economic Entomology, 103(4), 1031-1038. https://doi.org/10.1603/ec10040

Strano, C. P., Malacrinò, A., Campolo, O., \& Palmeri, V. (2018). Influence of host plant on Thaumetopoea pityocampa gut bacterial community. Microbial Ecology, 75(2), 487-494. https://doi.org/10.1007/s0024 8-017-1019-6

Šustr, V., Chroňáková, A., Semanová, S., Tajovský, K., \& Šimek, M. (2014). Methane production and methanogenic archaea in the digestive tracts of millipedes (Diplopoda). PLoS One, 9(7), e102659. https://doi. org/10.1371/journal.pone.0102659

Weedon, J. T., Kowalchuk, G. A., Aerts, R., van Hal, J., van Logtestijn, R., Taş, N., ... van Bodegom, M. P. (2012). Summer warming accelerates sub-arctic peatland nitrogen cycling without changing enzyme pools or microbial community structure. Global Change Biology, 18(1), 138150. https://doi.org/10.1111/j.1365-2486.2011.02548.x

Taffner, J., Erlacher, A., Bragina, A., Berg, C., Moissl-Eichinger, C., \& Berg, G. (2018). What is the role of Archaea in plants? New insights from 
the vegetation of alpine bogs. mSphere, 3(3), e00122-18. https://doi. org/10.1128/msphere.00122-18

Tinker, K. A., \& Ottesen, E. A. (2016). The core gut microbiome of the American cockroach, Periplaneta americana, is stable and resilient to dietary shifts. Applied and Environmental Microbiology, 82(22), 66036610. https://doi.org/10.1128/AEM.01837-16

Todd, E. L., \& Poole, R. W. (1980). Keys and illustrations for the armyworm moths of the noctuid genus Spodoptera guenee from the Western Hemisphere. Annals of the Entomological Society of America, 73(6), 722-738.

Visotto, L. E., Oliveira, M. G., Ribon, A. O., Mares-Guia, T. R., \& Guedes, R. N. (2009). Characterization and identification of proteolytic bacteria from the gut of the velvetbean caterpillar (Lepidoptera: Noctuidae). Environmental Entomology, 38, 1078-1085. https://doi. org/10.1603/022.038.0415

Voirol, L. R. P., Frago, E., Kaltenpoth, M., Hilker, M., \& Fatouros, N. E. (2018). Bacterial symbionts in lepidoptera: Their diversity, transmission, and impact on the host. Frontiers in Microbiology, 9, 556. https:// doi.org/10.3389/fmicb.2018.00556

Wang, J., Chung, S. H., Peiffer, M., Rosa, C., Hoover, K., Zeng, R., \& Felton, G. W. (2016). Herbivore oral secreted bacteria trigger distinct defense responses in preferred and non-preferred host plants. Journal of Chemical Ecology, 42(6), 463-474. https://doi.org/10.1007/ s10886-016-0712-0

Wang, Q., Garrity, G. M., Tiedje, J. M., \& Cole, J. R. (2007). Naïve bayesian classifier for rapid assignment of rRNA sequences into the new bacterial taxonomy. Applied and Environmental Microbiology, 73(16), 5261-5267. https://doi.org/10.1128/AEM.00062-07

Xia, X., Gurr, G. M., Vasseur, L., Zheng, D., Zhong, H., Qin, B., ... You, M. (2017). Metagenomic sequencing of diamondback moth gut microbiome unveils key holobiont adaptations for herbivory. Frontiers in Microbiology, 8, 663. https://doi.org/10.3389/fmicb.2017.00663

Xia, X., Zheng, D., Zhong, H., Qin, B., Gurr, G. M., Vasseur, L., ... You, M. (2013). DNA sequencing reveals the midgut microbiota of diamondback moth, Plutella xylostella (L.) and a possible relationship with insecticide resistance. PLoS One, 8, e68852.

\section{SUPPORTING INFORMATION}

Additional supporting information may be found online in the Supporting Information section.

How to cite this article: Ugwu JA, Liu M, Sun H, Asiegbu FO. Microbiome of the larvae of Spodoptera frugiperda (J.E. Smith) (Lepidoptera: Noctuidae) from maize plants. J Appl Entomol.

2020;144:764-776. https://doi.org/10.1111/jen.12821 